\title{
Implementasi Pendekatan Taktis dalam Pembelajaran Pendidikan Jasmani Terhadap Motivasi, Kebugaran Jasmani dan Kemampuan Motorik
}

\author{
Ade Rokhayati ${ }^{1}$, Lutfi Nur ${ }^{2}$, Elan $^{3}$, Gilar Gandana ${ }^{4}$ \\ Universitas Pendidikan Indonesia, Kampus Tasikmalaya \\ Corresponding author: lutfinur@upi.edu
}

\begin{abstract}
Abstrak. Penelitian ini dilatar belakangi oleh fakta di lapangan mengenai kondisi pembelajaran pendidikan jasmani saat ini, yang kecenderungannya masih menggunakan pendekatan konvensional. Proses pembelajaran ini cenderung membuat bosan dan kurang antusiasnya siswa dalam mengikuti proses pembelajaran. Penelitian ini dilakukan untuk mengetahui kontribusi pendekatan taktis dalam pembelajaran pendidikan jasmani terhadap motivasi, kebugaran jasmani dan kemampuan motorik. Penelitian ini menggunakan metode eksperimen dengan desain penelitian yang digunakan dalam penelitian ini adalah quasi eksperimen dengan bentuk Non equivalent Pretest-Posttest Control Group Design. Subjek siswa yang akan dilibatkan adalah siswa kelas V sekolah dasar di MI Asshulaha dan SD Sukamanah 2. Jumlah sampel dalam penelitian ini sebanyak 28 orang sesuai jumlah di kelas VB MI Asshulaha dan 28 orang di kelas V SD Sukamanah 2. Instrumen dalam penelitian ini menggunakan angket motivasi belajar, tes kebugaran jasmani dan tes kemampuan motorik. Hasil penelitian ini menunjukkan bahwa 1) peningkatan motivasi belajar siswa yang diajar melalui pendekatan pembelajaran taktis lebih baik daripada siswa yang diajar melalui pendekatan pembelajaran konvensional, 2) peningkatan kebugaran jasmani siswa yang diajar melalui pendekatan pembelajaran taktis lebih baik daripada siswa yang diajar melalui pendekatan pembelajaran konvensional. 3) peningkatan kemampuan motorik siswa yang diajar melalui pendekatan pembelajaran taktis lebih baik daripada siswa yang diajar melalui pendekatan pembelajaran konvensional.
\end{abstract}

\section{Pendahuluan}

Program pendidikan jasmani dan olahraga di sekolah diarahkan pada potensi aspek-aspek pengembangan utuh siswa. Prosesnya lebih mengutamakan pada elaborasi hubungan kuat antara sisi sosial-emosional, kognitif reflektif, gerak keterampilan siswa, dan sisi psikologis siswa. Pengajaran penjas sangatlah diharapkan dapat bermanfaat dalam menopang kualitas hidup siswa yang lebih bermakna baik bagi kehidupan siswa di masa kini maupun di masa mendatang. Suherman (2009: 50) menjelaskan proses pembelajaran pada dasarnya merupakan interaksi pedagogis antara guru, siswa, materi, dan lingkungannya. Dalam kaitannya dengan proses pembelajaran pendidikan jasmani, sesuai pengamatan penulis selama ini proses mengajar masih cenderung menggunakan pendekatan pembelajaran konvensional yang menekankan pada penguasaan keterampilan menjadi tujuan utama pembelajaran tanpa memperhatikan karakteristik siswa dan jenis olahraganya. Sehingga tanpa disadari pengajar terlalu fokus pada keterampilan gerak khususnya, melupakan hal yang sama pentingnya, yaitu aspek kognitif, afektif dan psikomotorik. Namun bila kita cermati, proses pembelajaran siswa di sekolah dasar itu seharusnya diutamakan pada pengembangan-pengembangan dasar seperti minat belajar, motivasi belajar, kebugaran jasmani dan lain-lain, yang nantinya akan menjadi bekal untuk 
jenjang selanjutnya. Artinya ketika fondasi dasar siswa sudah baik, maka itu akan berdampak pada hasil belajar yang lebih optimal.

Pemilihan dan penggunaan pendekatan pembelajaran yang tepat dalam proses pembelajaran praktek dengan tujuan agar hasil belajar lebih optimal. Untuk itu, perlu dikembangkan pendekatan pembelajaran yang lebih efektif dan efisien, sesuai dengan tuntutan dan karakteristik siswa yang belajar. Oleh sebab itu, pengajar harus dapat mensiasati atau mengatasi masalah tersebut, dengan tidak menggunakan pendekatan pembelajaran yang asal-asalan, artinya pengajar harus mampu merencanakan, menetapkan dan menerapkan berbagai upaya yang berhubungan dengan kegiatan belajar-mengajar, tentunya pemilihan pendekatan pembelajaran sangatlah efektif untuk terciptanya hasil belajar yang diharapkan berdasarkan tuntutan dan karakteristik siswa. Dengan kata lain, pendidik harus memiliki strategi belajar-mengajar yang merupakan hasil pilihan yang disesuaikan dengan situasi, kondisi, dan tujuan pengajaran tertentu, karena hal tersebut dapat berbeda-beda.

Pada saat ini, pembelajaran yang sering digunakan dalam pelaksanaan kegiatan belajar mengajar, salah satu diantaranya adalah pendekatan pembelajaran konvensional yang mayoritas digunakan oleh para pengajarnya. Gambaran pelaksanaan pendekatan pembelajaran konvensional lebih menekankan kepada pembelajaran keterampilan teknik atau beberapa teknik dasar secara sendiri-sendiri atau terpisah-pisah, sementara makna pemahaman permainan itu sendiri sering terabaikan. Dengan pola pendekatan konvensional pengajar sering menghabiskan waktu pembelajarannya hanya untuk mempelajari teknik dasar saja, ada kesan pada siswa pendekatan semacam ini membosankan dan kurang menarik karena situasi belajar terkesan monoton.

Meskipun pendekatan pembelajaran konvensional ini diduga dapat meningkatkan penguasaan keterampilan teknik dasar, namun ternyata mendapatkan kritikan, salah satunya dikemukakan oleh Griffin, et.al., (1997: 8) yang menyatakan bahwa "though this format might improve technique, it has been criticizen for teaching skill before students can grasp their significance within the game." Maksudnya, keterampilan yang diajarkan sebelum subjek ajar dapat mengerti keterkaitannya dengan situasi bermain yang sesungguhnya, hasilnya dapat menghilangkan esensi dari permainan itu sendiri.

Sesuai dengan kritikannya, Griffin, et.al dalam Suparlan (2009) mengembangkan sebuah pendekatan pembelajaran yang dalam pelaksanaannya menerapkan sistem pola permainan yang sesungguhnya. Pola pendekatan pembelajaran dilakukan melalui aktivitas bermain, dan pembelajaran penguasaan teknik dasar dilakukan bersamaan dengan pola bermain. Pendekatan pembelajaran yang dimaksud adalah pendekatan pembelajaran taktis.

Berdasarkan uraian di atas, peneliti merasa perlu untuk melakukan penelitian dalam hal mengimplementasikan suatu pendekatan taktis yang nantinya dibandingkan dengan pendekatan konvensional terhadap peningkatan motivasi belajar di sekolah dasar. Penelitian ini penulis anggap memiliki nilai penting dalam kaitannya dengan upaya peningkatan kualitas pembelajaran baik dalam intrakurikuler maupun ekstrakurikuler berbagai cabang olahraga yang pada gilirannya dapat membantu meningkatkan hasil belajar dalam pendidikan jasmani di sekolah dasar. Selanjutnya dengan hal tersebut akan berkontribusi pada hasil belajar yang lebih baik lagi. Karena apabila masalah ini terus berkelanjutan dan tidak diteliti dari perspektif yang telah diuraikan di atas serta dikaji, diduga akan berpengaruh terhadap pencapaian hasil belajar secara keseluruhan yang tidak optimal.

\section{Pendekatan Taktis dan Pendekatan Konvensional}

Pendekatan taktis merupakan pendekatan yang menghubungkan taktik dan keterampilan dalam konteks permainan olahraga (Fernando, 2014). Pendekatan pembelajaran taktis dalam pengajaran pendidikan jasmani orientasinya menggunakan minat siswa sebagai suatu struktur permainan untuk mempromosikan pengembangan keterampilan dan pengetahuan taktikal yang diperlukan untuk penampilan permainan. Dengan kata lain melalui pendekatan pembelajaran taktis, suasana 
pembelajaran lebih menarik dan merangsang minat siswa dalam belajar. Karena sistematika pelaksanaan pembelajaran diawali dengan aktivitas bermain, walaupun dalam nuansa dimodifikasi, baik itu dimodifikasi dalam hal lingkungan pembelajaran maupun peraturan permainan. Melalui pendekatan pembelajaran taktis, para siswa yang terlibat dalam kegiatan pembelajaran permainan akan diarahkan kepada pemahaman terhadap pola-pola bermain. Adapun pola-pola kegiatan pembelajaran dengan menggunakan pendekatan taktis, lebih rinci dijelaskan oleh Metzler (2000: 369), langkahlangkahnya sebagai berikut: (1) Game form, students are directed to the various game forms, (2) teaching for understanding, teacher stops the keep-away game and asks questions, (3) drills for skill development, teacher explains and demonstrates the proper defensive stance to the class, (4) return to game form, students play "keep-away" again, (5) review and closure, teacher reviews the key concepts and some important principles of game forms that students have done.

Pendekatan pembelajaran konvensional merupakan pendekatan pembelajaran yang cenderung lebih ditekankan kepada penguasaan unsur-unsur teknik dasar yang dilakukan secara berulang-ulang, dan penerapan pembelajarannya difokuskan kepada penguasaan teknik dasar terlebih dahulu dan selanjutnya kepada permainan. Hal demikian berdampak terhadap situasi dan kondisi pembelajaran yang cenderung monoton dan membosankan, sehingga kurang merangsang minat belajar siswa. Selain itu, siswa yang belajar menjadi kurang konsentrasi dan cenderung mempengaruhi motivasi dalam proses pembelajaran pendidikan jasmani.

Forrest, Web \& Pearson yang dikutip Yudiana dalam Nur (2013: 78), bahwa "format kegiatan pembelajaran pendekatan teknis meliputi pemanasan, pengembangan keterampilan teknik dasar, modifikasi permainan, dan kemudian bermain."Berdasarkan uraian di atas, pada prinsipnya kegiatan pembelajaran melalui pendekatan teknis yaitu lebih diutamakan kepada penguasaan keterampilan teknik dasar terlebih dahulu, sebelum melangkah ke pola-pola permainan.

\section{Metode}

Metode penelitian yang digunakan dalam penelitian ini adalah metode eksperimen untuk melihat peningkatan motivasi belajar pendidikan jasmani melalui pendekatan pembelajaran taktis. Desain penelitian yang digunakan dalam penelitian ini adalah Quasi Eksperimen dengan bentuk Nonequivalent Pretest-Posttest Control Group Design. Hal tersebut merujuk kepada Creswell (2010, hlm 132) bahwa penelitian ini akan melakukan Pretest dan Posttest terhadap dua kelas anak sekolah dasar kelas $\mathrm{V}$ untuk dilihat hal dalam pembelajarannya.

\begin{tabular}{cccc} 
Kelompok & Pretest & Perlakuan & Posttest \\
\hline Eksperimen & O1 & X & O2 \\
Kontrol & O3 & - & O4 \\
\hline
\end{tabular}

Subjek siswa yang akan dilibatkan adalah siswa kelas V sekolah dasar di MI Asshulaha dan SD Sukamanah 2. Jumlah sampel dalam penelitian ini sebanyak 28 orang sesuai jumlah di kelas VB MI Asshulaha dan 28 orang di kelas V SD Sukamanah 2.

Instrumen yang digunakan dalam penelitian ini ada tiga, yaitu 1) instrumen pengukuran motivasi yang dipergunakan Hidayat, dkk (2010) dalam mengukur tingkat partisipasi olahraga siswa sekolah dasar. Skala ini dibangun oleh tiga dimensi konstruk motivasi yaitu motivasi intrinsik, motivasi ekstrinsik dan amotivasi. Ketiga dimensi dielaborasi menjadi tujuh indikator, yaitu external regulation, introjections regulation, identified regulation, intrinsic motivation to know, intrinsic motivation toward, intrinsic motivation to experience stimulation, dan amotivation yang berdasarkan hasil analisis reliabilitas konsistensi internal diperoleh skor Alpha Cronbah terentang dari 0,66 sampai 0,81 dengan rerata 0,74 . 2) instrumen kebugaran jasmani yang terdiri dari item tes lari cepat 40 meter, angkat tubuh 30 detik, baring duduk 30 detik, loncat tegak dan lari 600 meter (Nurhasan dan Cholil, 
2007:118); 3) instrumen kemampuan motorik yang terdiri dari item tes shuttle-run $4 \times 10$ meter, lempat tangkap bola jarak satu meter dengan tembok, stork stand positional balance (keseimbangan) dan lari cepat 30 meter (Nurhasan dan Cholil, 2007:135-137).

\section{Hasil dan Pembahasan}

Untuk dapat memberikan gambaran secara umum tentang data yang telah diperoleh dari hasil penelitian, maka data-data tersebut dianalisis. kemudian dicari nilai rata-rata (mean) dan simpangan baku (standar deviasi). Berikut statistik deskriftip hasil pengukuran variabel penelitian disajikan dalam tabel dibawah ini.

Tabel 4.1 Statistik Deskriftip Variabel Motivasi Belajar

\begin{tabular}{cccc} 
Waktu Pengukuran & N & Mean & Std. Deviation \\
\hline Tes Awal Kelompok Kontrol & 28 & 68.50 & 8.63 \\
Tes Akhir Kelompok Kontrol & 28 & 107.28 & 7.71 \\
Gain Skor & $\mathbf{2 8}$ & $\mathbf{3 8 . 7 8}$ & $\mathbf{6 . 2 3}$ \\
Tes Awal Kelompok Eksperimen & 28 & 71.57 & 6.37 \\
Tes Akhir Kelompok Eksperimen & 28 & 117.96 & 8.31 \\
Gain Skor & $\mathbf{2 8}$ & $\mathbf{4 6 . 3 9}$ & $\mathbf{6 . 9 3}$ \\
\hline
\end{tabular}

Berdasarkan tabel 4.1 diperoleh statistic deskriftip hasil pengukuran pada kelompok kontrol untuk variabel motivasi pada tes awal $(M=68,50$ dan $S D=8,63)$, tes akhir $(M=107,28$ dan $S D=7,71)$, kemudian selisih antara tes awal dan tes akhir $(\mathrm{M}=38,78$ dan $\mathrm{SD}=6,23)$. Sedangkan pada kelompok eksperimen diperoleh statistic deskriftip pada tes awal $(M=71,57$ dan $S D=6,37)$, tes akhir $(M=117,96$ dan $\mathrm{SD}=8,31)$, kemudian selisih antara tes awal dan tes akhir $(\mathrm{M}=46,39$ dan $\mathrm{SD}=6,93)$.

Tabel 4.2 Statistik Deskriftip Variabel Kebugaran Jasmani

\begin{tabular}{cccc} 
Waktu Pengukuran & N & Mean & Std. Deviation \\
\hline Tes Awal Kelompok Eksperimen & 28 & 49.99 & 6.29 \\
Tes Akhir Kelompok Eksperimen & 28 & 53.88 & 8.79 \\
Gain Skor & 28 & 3.88 & 4.34 \\
Tes Awal Kelompok Kontrol & 28 & 49.99 & 7.88 \\
Tes Akhir Kelompok Kontrol & 28 & 51.90 & 7.39 \\
Gain Skor & 28 & 1.90 & 1.88 \\
\hline
\end{tabular}

Berdasarkan tabel 4.2 diperoleh statistic deskriftip hasil pengukuran pada kelompok eksperimen untuk variabel motivasi pada tes awal $(M=49,99$ dan $S D=6,29)$, tes akhir $(M=53,88$ dan $S D=8,79)$, kemudian selisih antara tes awal dan tes akhir $(\mathrm{M}=3.88$ dan $\mathrm{SD}=4,34)$. Sedangkan pada kelompok kontrol diperoleh statistic deskriftip pada tes awal $(\mathrm{M}=49,99$ dan $\mathrm{SD}=7,88)$, tes akhir $(\mathrm{M}=51,90$ dan $\mathrm{SD}=7,39)$, kemudian selisih antara tes awal dan tes akhir $(\mathrm{M}=1,90$ dan $\mathrm{SD}=1,88)$.

Tabel 4.3 Statistik Deskriftip Variabel Kemampuan Motorik

\begin{tabular}{cccc} 
Waktu Pengukuran & N & Mean & Std. Deviation \\
\hline Tes Awal Kelompok Eksperimen & 28 & 50.00 & 6.00 \\
Tes Akhir Kelompok Eksperimen & 28 & 55.76 & 5.89 \\
Gain Skor & 28 & 5.75 & 2.28 \\
Tes Awal Kelompok Kontrol & 28 & 49.99 & 4.80 \\
Tes Akhir Kelompok Kontrol & 28 & 53.06 & 4.65 \\
Gain Skor & 28 & 3.06 & 0.99 \\
\hline
\end{tabular}


Berdasarkan tabel 4.3 diperoleh statistic deskriftip hasil pengukuran pada kelompok eksperimen untuk variabel kemampuan motorik pada tes awal $(M=50,00$ dan $S D=6,00)$, tes akhir $(M=55,76$ dan $\mathrm{SD}=5,89)$, kemudian selisih antara tes awal dan tes akhir $(\mathrm{M}=5,75$ dan $\mathrm{SD}=2,28)$. Sedangkan pada kelompok kontrol diperoleh statistic deskriftip pada tes awal $(\mathrm{M}=49,99$ dan $\mathrm{SD}=4,80)$, tes akhir $(\mathrm{M}=53,06$ dan $\mathrm{SD}=4,65)$, kemudian selisih antara tes awal dan tes akhir $(\mathrm{M}=3,06$ dan $\mathrm{SD}=0,99)$.

\section{Uji Asumsi}

Setelah nilai rata-rata dan simpangan baku kedua kelompok sampel diketahui, maka langkah selanjutnya adalah melakukan uji normalitas dari data hasil tes tersebut dengan menggunakan uji kenormalan Kolmogorov-swirnov. Tujuannya untuk menetapkan teknik pengujian hipotesis yaitu jika data berdistribusi normal, maka menggunakan pengujian parametrik dan sebaliknya jika data berdistribusi tidak normal, maka menggunakan pengujian non parametrik. Hasil dari pengujian tersebut dapat dilihat dalam Tabel 4.4 berikut ini.

Tabel 4.4 Hasil Pengujian Normalitas Variabel Penelitian

\begin{tabular}{|c|c|c|c|c|c|}
\hline \multirow{2}{*}{ Variabel } & \multirow{2}{*}{ Kelompok } & \multicolumn{3}{|c|}{ Kolmogorov-Smirnov ${ }^{\mathrm{a}}$} & \multirow{2}{*}{ Keterangan } \\
\hline & & Statistic & Df & Sig. & \\
\hline \multirow[t]{2}{*}{ Motivasi } & $\mathrm{KE}$ & 0,14 & 28 & 0,18 & Normal \\
\hline & KK & 0,10 & 28 & 0,20 & Normal \\
\hline \multirow[t]{2}{*}{ Kebugaran Jasmani } & $\mathrm{KE}$ & 0,10 & 28 & 0,20 & Normal \\
\hline & KK & 0,13 & 28 & 0,20 & Normal \\
\hline \multirow{2}{*}{ Kemampuan Motorik } & $\mathrm{KE}$ & 0,21 & 28 & 0,20 & Normal \\
\hline & KK & 0,18 & 28 & 0,18 & Normal \\
\hline
\end{tabular}

Ket : KE (Kelompok Eksperimen), KK (Kelompok Kontrol)

Berdasarkan tabel 4.4 hasil analisis menunjukan bahwa pada variabel Motivasi diperoleh nilai Kolmogorov Smirnov untuk kelompok eksperimen (Statistik $=0,14$, sig $=0,18$ ), dan kelompok kontrol (Statistik $=0,10$, sig $=0,20$ ), kemudian pada variabel kebugaran jasmani diperoleh nilai kolmogrov smirnov untuk kelompok eksperimen (Statistik $=0,10$, sig $=0,20$ ), dan kelompok kontrol (Statistik = 0,13 , sig $=0,20$ ), sedangkan pada variabel kemampuan motorik diperoleh nilai kolmogrov smirnov untuk kelompok eksperimen (Statistik $=0,21$, sig $=0,20$ ), dan kelompok kontrol (Statistik =0,18, sig = $0,18)$.

Metode pengambilan keputusan untuk uji normalitas yang digunakan yaitu jika nilai signifikansi $>0,05$ maka data tersebut berdistribusi normal dan jika nilai signifikansi $<0,05$ maka data tersebut tidak berdistribusi normal (Priyanto 2010:58). Berdasarkan nilai yang diperoleh dari tabel 4.4 nilai p_value atau sig dari ketiga variabel diatas terbukti mempunyai nilai diatas 0,05 . Dengan demikian ketiga variabel pada penelitian ini berdistribusi normal, baik pada variabel motivasi, kebugaran jasmani maupun kemampuan motorik.

\section{Uji Hipotesis}

Untuk menguji hipotesis yang sudah ditentukan dalam bab sebelumnya teknik analisis statistic yang digunakan adalah teknik analisis uji independent sampel t test, hal tersebut bertujuan untuk melihat perbedaan pengaruh antara kelompok eksperimen (pendekatan taktis) dan kelompok kontrol (pendekatan konvensional) terhadap variabel independent (Motivasi, Kebugaran Jasmani dan Kemampuan Motorik). Berikut hasil analisis pengujian independent sampel t test disajikan pada tabel dibawah ini : 
Tabel 4.5 Statistik Deskriftip Hasil Analisis Independent Sampel T test

\begin{tabular}{cccccc} 
Variabel & Group & N & Mean & SD & SE M \\
\hline \multirow{2}{*}{ Motivasi } & K Kontrol & 28 & 38.78 & 6.23 & 1.17 \\
& K Eksperimen & 28 & 46.39 & 6.93 & 1.30 \\
\multirow{2}{*}{ Kebugaran Jasmani } & K Eksperimen & 28 & 3.88 & 4.34 & 0.82 \\
& K Kontrol & 28 & 1.90 & 1.88 & 0.35 \\
\multirow{2}{*}{ Kemampuan Motorik } & K Eksperimen & 28 & 5.75 & 2.28 & 0.43 \\
& K Kontrol & 28 & 3.06 & 0.99 & 0.18 \\
\hline
\end{tabular}

Ket : SD (standar deviasi), SE M (Standar Error of Mean)

Tabel 4.6 Hasil Analisis Independent Sampel T test

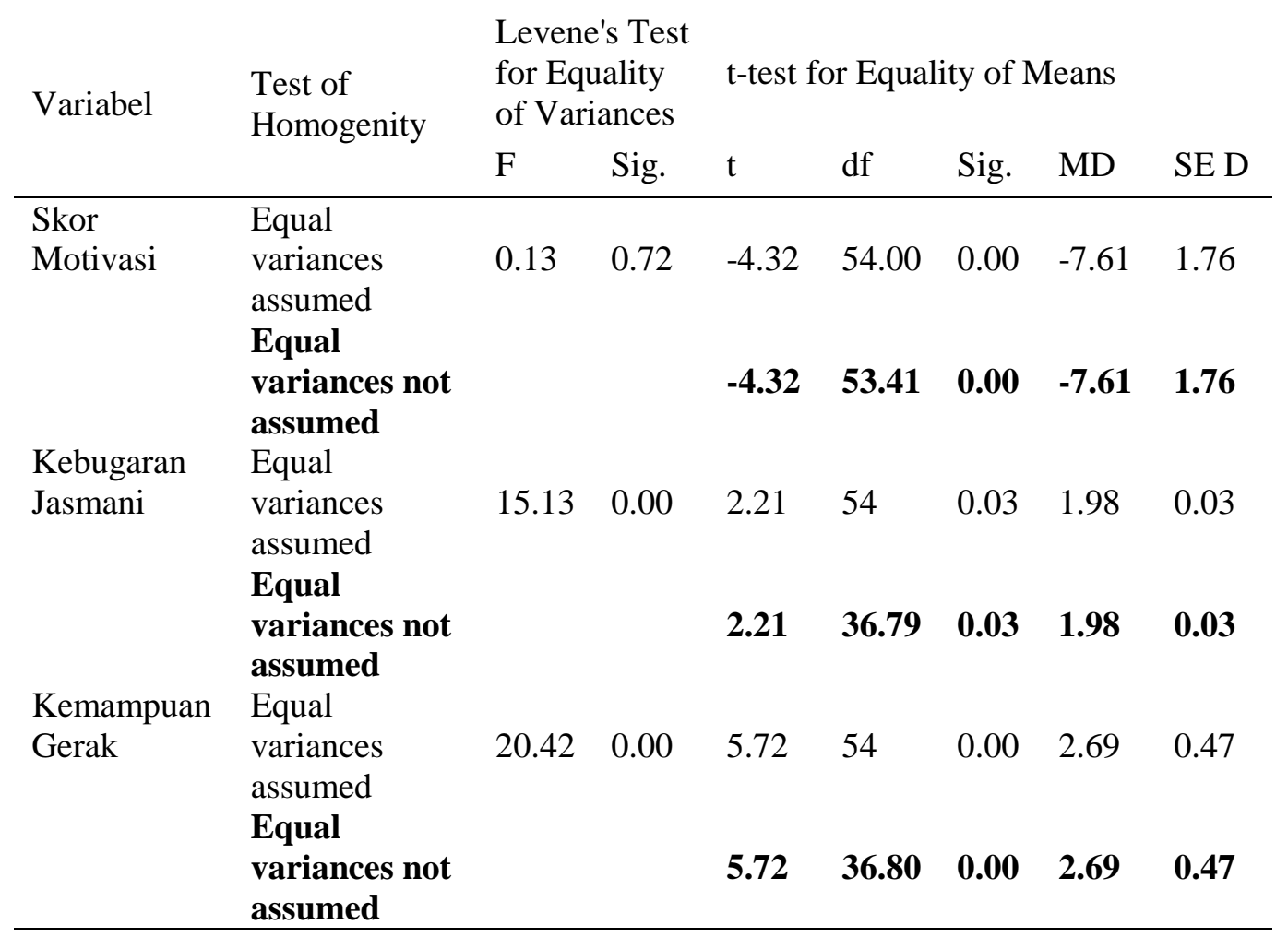

Ket : MD (Mean Different), SE D (Standar Error Different)

Berdasarkan hasil analisis yang disajikan pada tabel 4.5 dan 4.6 terbukti pada variabel motivasi diperoleh nilai $\mathrm{t}=-4.32$ dan signifikan pada nilai $p_{-}$value $=0.00(0.00<0.05)$. Hasil tersebut menunjukan bahwa terdapat perbedaan yang signifikan antara kelompok eksperimen (pendekatan taktik) dan kelompok kontrol (pendekatan konvensional). Selain itu apabila kita lihat pada tabel 4.5 diperoleh nilai mean untuk kelompok eksperimen (pendekatan taktik) sebesar 46,39 dan kelompok kontrol (pendekatan konvensional) sebesar 38.78. hal tersebut membuktikan bahwa kelompok eksperimen (pendekatan taktik) memberikan pengaruh yang lebih tinggi dari pada kelompok kontrol (pendekatan konvensional) terhadap peningkatan motivasi belajar. Hasil tersebut menunjukan bahwa hipotesis yang diajukan dapat diterima sesuai dengan hasil dari analisis stastistik.

Selanjutnya hasil analisis yang disajikan pada variabel kebugaran jasmani terbukti diperoleh nilai $\mathrm{t}=$ 2.21 dan signifikan pada nilai $p_{\text {_value }}=0.03(0.03<0.05)$. Hasil tersebut menunjukan bahwa terdapat 
perbedaan yang signifikan antara kelompok eksperimen (pendekatan taktik) dan kelompok kontrol (pendekatan konvensional) pada variabel kebugaran jasmani. Kemudian pada tabel 4.5 diperoleh nilai mean untuk kelompok eksperimen (pendekatan taktik) sebesar 3.89 dan kelompok kontrol (pendekatan konvensional) sebesar 1.90. hal tersebut membuktikan bahwa kelompok eksperimen (pendekatan taktik) memberikan pengaruh yang lebih tinggi dari pada kelompok kontrol (pendekatan konvensional) terhadap peningkatan kebugaran jasmani. Oleh sebab itu, hasil analisis menunjukan bahwa hipotesis yang diajukan dapat diterima sesuai dengan hasil dari analisis stastistik.

Kemudian hasil analisis yang disajikan pada variabel kemampuan motorik terbukti diperoleh nilai $\mathrm{t}=$ 5.73 dan signifikan pada nilai $p_{\text {_value }}=0.00(0.00<0.05)$. Hasil tersebut menunjukan bahwa terdapat perbedaan yang signifikan antara kelompok eksperimen (pendekatan taktik) dan kelompok kontrol (pendekatan konvensional) pada variabel kemampuan motorik. Kemudian pada tabel 4.5 diperoleh nilai mean untuk kelompok eksperimen (pendekatan taktik) sebesar 5.76 dan kelompok kontrol (pendekatan konvensional) sebesar 3.06. hal tersebut membuktikan bahwa kelompok eksperimen (pendekatan taktik) memberikan pengaruh yang lebih tinggi dari pada kelompok kontrol (pendekatan konvensional) terhadap peningkatan kemampuan motorik siswa. Oleh sebab itu, hasil analisis menunjukan bahwa hipotesis yang diajukan dapat diterima sesuai dengan hasil dari analisis stastistik.

Tabel 4.7 Rangkuman Hasil Analisis Independnt Sampel t Test

\begin{tabular}{ccccc} 
Variabel & $\begin{array}{c}\text { Pendekatan } \\
\text { Taktik }\end{array}$ & $\begin{array}{c}\text { Pendekatan } \\
\text { Konvensional }\end{array}$ & Sig & Keterangan \\
\hline Motivasi & $\mathrm{M}=46.39$ & $\mathrm{M}=38.78$ & 0.00 & $\begin{array}{l}\text { Berbeda Signifikan } \\
\text { Hipotesis diterima } \\
\text { Kebugaran Jasmani }\end{array}$ \\
$\mathrm{M}=3.88$ & $\mathrm{M}=1.90$ & 0.03 & $\begin{array}{c}\text { Berbeda Signifikan } \\
\text { Hipotesis diterima }\end{array}$ \\
$\begin{array}{c}\text { Kemampuan } \\
\text { Motorik }\end{array}$ & $\mathrm{M}=5.75$ & $\mathrm{M}=3.06$ & 0.00 & $\begin{array}{c}\text { Berbeda Signifikan } \\
\text { Hipotesis diterima }\end{array}$ \\
\hline
\end{tabular}

Tabel 4.8 Hasil Analisis Multivariat pengaruh variabel independent terhadap variabel dependent secara bersama-sama

\begin{tabular}{|c|c|c|c|c|c|c|}
\hline & & Mul & ivariate Tests ${ }^{\mathrm{a}}$ & & & \\
\hline & Effect & $\mathbf{F}$ & $\begin{array}{c}\text { Hypothesis } \\
\text { df }\end{array}$ & Error df & Sig. & $\begin{array}{l}\text { Partial Eta } \\
\text { Squared }\end{array}$ \\
\hline & Pillai's Trace & 892.15 & 3.00 & 52.00 & 0.00 & 0.981 \\
\hline & Wilks' Lambda & 892.15 & 3.00 & 52.00 & 0.00 & 0.981 \\
\hline Intercept & Hotelling's Trace & 892.15 & 3.00 & 52.00 & 0.00 & 0.981 \\
\hline & Roy's Largest Root & 892.15 & 3.00 & 52.00 & 0.00 & 0.981 \\
\hline & Pillai's Trace & 19.72 & 3.00 & 52.00 & 0.00 & 0.532 \\
\hline & Wilks' Lambda & 19.72 & 3.00 & 52.00 & 0.00 & 0.532 \\
\hline Group & Hotelling's Trace & 19.72 & 3.00 & 52.00 & 0.00 & 0.532 \\
\hline & Roy's Largest Root & 19.72 & 3.00 & 52.00 & 0.00 & 0.532 \\
\hline
\end{tabular}

Berdasarkan hasil analisis multivariate test diperoleh nilai F pada kolom Wilks Lambada sebesar 19.72 dan signfikan pada $p_{-}$value $0.00(0.00<0.05)$. hasil tersebut menunjukan bahwa terdapat pengaruh yang signifikan dari kedua kelompok independent baik pada kelompok eksperimen maupun kelompok kontrol terhadap variabel dependent (motivasi, kebugaran jasmani dan kemampuan gerak) secara bersama-sama. Selain itu hasil partial eta squared menunjukan nilai 0.532 . hal tersebut menunjukan 
bahwa kedua kelompok memberikan pengaruh sebesar $53.2 \%$ terhadap pengingkatan variabel dependent (motivasi, kebugaran jasmani dan kemampuan gerak) secara bersama-sama.

Tabel 4.9 Hasil Analisis Univariat pengaruh variabel independent terhadap variabel dependent

\begin{tabular}{|c|c|c|c|c|c|}
\hline \multirow{2}{*}{ Source } & \multicolumn{3}{|c|}{ Tests of Between-Subjects Effects } & \multirow[b]{2}{*}{ Sig. } & \multirow[b]{2}{*}{$\begin{array}{c}\text { Partial Eta } \\
\text { Squared }\end{array}$} \\
\hline & Dependent Variable & df & $\mathbf{F}$ & & \\
\hline \multirow{3}{*}{ Corrected Model } & Keterampilan Motorik & 1 & 32.790 & 0.00 & 0.378 \\
\hline & Kebugaran Jasmani & 1 & 4.882 & 0.03 & 0.083 \\
\hline & Motivasi & 1 & 18.637 & 0.00 & 0.257 \\
\hline \multirow{3}{*}{ Intercept } & Keterampilan Motorik & 1 & 351.058 & 0.00 & 0.867 \\
\hline & Kebugaran Jasmani & 1 & 41.895 & 0.00 & 0.437 \\
\hline & Motivasi & 1 & 2336.666 & 0.00 & 0.977 \\
\hline \multirow{3}{*}{ Group } & Keterampilan Motorik & 1 & 32.790 & 0.00 & 0.378 \\
\hline & Kebugaran Jasmani & 1 & 4.882 & 0.03 & 0.083 \\
\hline & Motivasi & 1 & 18.637 & 0.00 & 0.257 \\
\hline
\end{tabular}

Selanjutnya hasil analisis pada tabel 4.9 menunjukan bahwa variabel independent memberikan pengaruh pada masing-masing variabel dependen. Hasil analisis tersebut dapat diuraikan sebagai berikut:

1. Kelompok pendekatan taktis mapun pendekatan konvensional memberikan pengaruh yang signifikan terhadap peningkatan keterampilan motoric dengan nilai $\mathrm{F}$ sebesar 32.790 dan signifikan pada $p \_v a l u e$ sebesar $0.00(0.00<0.05)$ dengan besaran pengaruh sebesar $37.8 \%$.

2. Kelompok pendekatan taktis mapun pendekatan konvensional memberikan pengaruh yang signifikan terhadap peningkatan kebugaran jasmani dengan nilai $F$ sebesar 4.882 dan signifikan

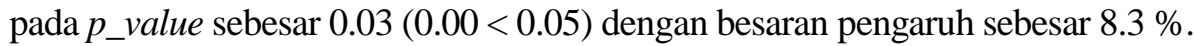

3. Kelompok pendekatan taktis mapun pendekatan konvensional memberikan pengaruh yang signifikan terhadap peningkatan Motivasi dengan nilai $F$ sebesar 18.63 dan signifikan pada p_value sebesar $0.00(0.00<0.05)$ dengan besaran pengaruh sebesar $25.7 \%$. Perbedaan pengaruh pendekatan taktis dengan pendekatan konvensional terhadap motivasi
belajar pendidikan jasmani.

Hasil penelitian ini menunjukkan pendekatan taktis memberikan kontribusi yang signifikan terhadap motivasi belajar siswa pada pembelajaran pendidikan jasmani di sekolah dasar. Pengujian hipotesis menunjukkan bahwa pendekatan pembelajaran taktis memberikan pengaruh yang lebih baik daripada pendekatan pembelajaran konvensional terhadap peningkatan motivasi belajar siswa sekolah dasar. Berdasarkan temuan peneliti, hal tersebut disebabkan antara lain: proses pelaksanaan pembelajaran dari kedua pendekatan pembelajaran, perkembangan psikologis siswa (tingkat partisipasi dan antusiasme) dan fakta data hasil tes mengenai motivasi belajar siswa sekolah dasar.

Berdasarkan temuan dilapangan, dalam fase perlakuan awal para siswa masih terlihat antusias dan bergairah dalam mengikuti pembelajaran kedua pendekatan pembelajaran yang diberikan oleh pengajarnya. Namun tidak lama kemudian di dalam pertemuan-pertemuan berikutnya mulai terlihat perbedaan antusiasme dan partisipasi para siswa dalam mengikuti proses belajar mengajar melalui pendekatan taktis dan konvensional. Faktanya siswa yang diajar melalui pendekatan taktis terlihat lebih antusias dalam mengikuti berbagai kegiatan, sedangkan siswa yang diajar melalui pendekatan konvensional terlihat mulai bosan dan berdampak pada tingkat kegairahan dan partisipasi mengikuti proses pembelajarannya.

Selain itu, dilihat daripada proses pelaksanaan pembelajarannya para siswa yang diajar melalui pendekatan taktis cenderung berpusat pada siswa, sedangkan pendekatan konvensional sebaliknya 
(berpusat pada guru). Artinya siswa lebih diberikan kebebasan bergerak dan mengembangkan dirinya dalam aktivitas pembelajaran pendidikan jasmani, sehingga melalui pola-pola kegiatan permainan yang dimodifikasi siswa terlihat bergairah mengikuti berbagai permainan yang secara tidak disadari aktivitas gerak yang dilakukan para siswa tersebut dilakukan dengan optimal serta waktu aktif belajarnya pun tinggi, yang akhirnya berdampak juga pada peningkatan kebugaran jasmani para siswa tersebut. Sejalan dengan penelitian yang dilakukan oleh Alison \& Thorpe (1997: 9-13), yang menyatakan dalam hasil penelitiannya bahwa pendekatan taktis yang diimplementasikan dalam permainan hoki dan bolabasket memberikan signifikansi yang tinggi terhadap kegairahan dan usaha belajar siswa. Selain itu smith (2015) dalam penelitiannya mengungkapkan juga bahwa para siswa lebih termotivasi belajarnya melalui pendekatan taktis dibandingkan dengan pendekatan intruksi langsung.

Berdasarkan temuan secara praktis dari hasil penelitian penulis, dan didukung oleh beberapa penemuan hasil penelitian sebelumnya. Ternyata peningkatan motivasi belajar siswa yang diajar melalui pendekatan taktis lebih baik daripada siswa yang diajar melalui pendekatan konvensional.

\section{Perbedaan pengaruh pendekatan taktis dengan pendekatan konvensional terhadap kebugaran jasmani.}

Pembelajaran taktis dan pendekatan pembelajaran teknis memberikan pengaruh yang signifikan terhadap kebugaran jasmani. Namun secara keseluruhan dalam penelitian ini, pendekatan taktis lebih baik daripada pendekatan teknis. Berdasarkan temuan peneliti, perbedaan tersebut disebabkan antara lain: Proses pelaksanaan pembelajaran dari kedua pendekatan pembelajaran, aktivitas pembelajaran siswa, dan fakta data hasil tes mengenai peningkatan kebugaran jasmani.

Pendekatan taktis merupakan pendekatan yang menghubungkan taktik dan keterampilan dalam konteks permainan olahraga (Fernando, 2014). Temuan di lapangan, bahwa proses pelaksanaan pembelajaran para siswa yang diajar melalui pendekatan taktis cenderung berpusat pada siswa, sedangkan pendekatan konvensional sebaliknya (berpusat pada guru). Pendekatan pembelajaran taktis dalam pembelajarannya tidak terlalu kaku dengan membatasi aktivitas para siswa, yang terjadi di awal pembelajaran guru langsung memberikan kebebasan pada para siswa untuk melakukan permainan olahraga yang telah dimodifikasi. Artinya, melalui pola-pola kegiatan permainan yang dimodifikasi siswa terlihat bergairah mengikuti berbagai permainan yang secara tidak disadari aktivitas gerak yang dilakukan para siswa tersebut dilakukan dengan optimal serta waktu aktif belajarnya pun tinggi, yang akhirnya berdampak pada peningkatan kebugaran jasmani para siswa tersebut. Casey dan Dyson (2009) mengungkapkan hal yang sama dalam hasil penelitiannya bahwa pendekatan taktikal mempunyai dampak baik yaitu memberikan kebebasan pada para siswa dalam proses pembelajarannya sehingga itu akan membuat aktivitasnya lebih aktif, walaupun hal itu akan membuat guru harus lebih ekstra mengawasi atau mengontrolnya.

Berdasarkan temuan secara praktis dari hasil penelitian penulis, dan didukung oleh beberapa penemuan hasil penelitian sebelumnya. Ternyata peningkatan kebugaran jasmani siswa yang diajar melalui pendekatan taktis lebih baik daripada siswa yang diajar melalui pendekatan konvensional. 


\section{Perbedaan pengaruh pendekatan taktis dengan pendekatan konvensional terhadap kemampuan motorik.}

Pembelajaran taktis dan pendekatan pembelajaran konvensional memberikan pengaruh yang signifikan terhadap kemampuan motorik. Namun secara keseluruhan dalam penelitian ini, pendekatan taktis lebih baik daripada pendekatan konvensional. Berdasarkan temuan peneliti, perbedaan tersebut disebabkan antara lain: proses pelaksanaan pembelajaran dari kedua pendekatan pembelajaran, perkembangan keterampilan gerak siswa, dan fakta data hasil tes mengenai kemampuan motorik.

Pendekatan taktis merupakan pendekatan pembelajaran yang menggunakan minat orientasi pembelajarannya, sehingga lingkungan belajar direkayasa sedemikian rupa agar apa yang diharapkan dapat tercapai. Rekayasa yang dimaksud adalah melalui modifikasi permainan olahraga yang disusun secara sitematis dari yang mudah hingga yang sukar serta para siswa diberi keleluasaan atau kebebasan dari awal untuk melakukan aktivitas yang diintruksikan oleh gurunya. Sehingga dengan hal demikian, terlihat bahwa temuan di lapangan para siswa lebih bergairah atau antusias dalam mengikuti proses pembelajarannya, yang secara tidak sadar bahwa mereka telah banyak melakukan hal bermakna didalamnya seperti perkembangan atau peningkatan kemampuan motoriknya.

Kemampuan motorik adalah kemampuan bawaan dan kemampuan yang dapat dipelajari yang mendasari penampilan sejumlah keterampilan gerak dan aktivitas fisik secara keseluruhan. Meskipun faktor bawaan dan lingkungan sama-sama berpengaruh, tetapi faktor bawaan dianggap sebagai kekuatan utama yang mempengaruhi kemampuan motorik. Ada delapan aspek kemampuan motorik, di antaranya yaitu kekuatan otot, daya tahan otot dan kardiovaskuler, kecepatan, kelincahan, keseimbangan, power otot, koordinasi mata-tangan dan mata-kaki (Subarjah, 2010).

Peningkatan kemampuan motorik siswa yang diajar melalui pendekatan taktis lebih tinggi dibandingkan siswa yang diajar melalui pendekatan konvensional, hal tersebut dikarenakan selain faktor bawaan setiap anak adalah faktor lingkungan proses pembelajaran yang dilakukan melalui kedua pendekatan pembelajaran dalam penelitian ini. Pendekatan taktis mendesain lingkungan proses pembelajarannya lebih kreatif sehingga lebih kompleks makna yang didapat oleh anak, baik dalam hal fisik, perkembangan gerak, dan afeksinya.

Berdasarkan temuan secara praktis dari hasil penelitian penulis, dan didukung oleh beberapa penemuan hasil penelitian sebelumnya. Ternyata peningkatan kemampuan motorik siswa yang diajar melalui pendekatan taktis lebih baik daripada siswa yang diajar melalui pendekatan konvensional.

\section{Conclusion}

Berdasarakan hasil pengolahan dan analisis data yang telah dilakukan, dapat ditarik kesimpulan sebagai berikut: 1) Peningkatan motivasi belajar siswa yang diajar melalui pendekatan pembelajaran taktis lebih baik daripada siswa yang diajar melalui pendekatan pembelajaran konvensional, 2) Peningkatan kebugaran jasmani siswa yang diajar melalui pendekatan pembelajaran taktis lebih baik daripada siswa yang diajar melalui pendekatan pembelajaran konvensional. 3) Peningkatan kemampuan motorik siswa yang diajar melalui pendekatan pembelajaran taktis lebih baik daripada siswa yang diajar melalui pendekatan pembelajaran konvensional. 


\section{Referensi}

[1] Alison, S., \& Thorpe, R. A Comparison of the Effectiveness of Two Approaches to Teaching Games Within Physical Education. A Skills Approach Versus a Games for Understanding Approach. The British Journal of Physical Education, 28 (3), 9-13, (1997).

[2] Casey A and Dyson B., The implementation of models-based practice in physical education through action research, European Physical Education Review, Vol. 15 (2), pp 175-199, (2009).

[3] Creswell, J. W. Research Design; Pendekatan Kualitatif, Kuantitatif, dan Mixed. Terjemahan Achmad Fawaid, et.al. Jogjakarta: Pustaka Pelajar, (2010).

[4] Fernando Ricky, Learning Approach Influence On Physical Fitness And Learning Skills Of Footbal. Primary Journal, Riau University, Vol 4, No 2, pp. 165-175, (2014).

[5] Griffin, L.L. Mitchell, S.A., dan Oslin, J.L. Teaching Sport Concept and Skills: A Tactical Games Approach. Illionois: Champaign, (1997).

[6] Hidayat, Y. Jurnal Pendidikan Jasmani dan Olahraga. FPOK : UPI, Vol. 4, No 2, (2010).

[7] Nurhasan dan Cholil. Tes dan Pengukuran Keolahragaan. Bandung: FPOK UPI, (2007).

[8] Metzler, M. W. Intructional Models for Physical Education. Massachusetts: Allyn and Bacon, (2000).

[9] Nur, L. Pengaruh Pendekatan Pembelajaran dan Kebugaran Jasmani Terhadap Hasil Belajar Keterampilan Bolabasket. Tesis. Program Studi Pendidikan Olahraga, Pascasarjana UPI Bandung, (2013).

[10] Smith L., Harve S., Savory L., Fairclough S., Kozub S., and Kerr C, Physical activity levels and motivational responses of boys and girls: A comparison of direct instruction and tactical games models of games teaching in physical education. European Physical Education Review, Vol. 21, No. 21, pp 93-113, (2015).

[11] Subarjah, H. Hasil Keterampilan Bermain Bulutangkis. Jurnal Cakrawala Pendidikan. Vol 3, No. 3, 16 halaman, (2010).

[12] Suherman, A. Revitalisasi Pengajaran dalam Pendidikan Jasmani. Bandung: CV. Bintang Warli Artika, (2009).

[13] Suparlan, A. Perbedaan Pengaruh Model Pembelajaran Taktis dan Teknis Berdasarkan Pada Kemampuan Keterampilan Awal yang Berbeda Terhadap Keterampilan Bermain Soft Ball. Tesis. Prodi POR Pascasarjana UPI, (2009). 